\title{
Motivations and repercussions regarding crack consumption: the collective discourse of users of a Psychosocial Care Center
}

\author{
Motivaçōes e repercussōes do consumo de crack: o discurso coletivo de usuários de um Centro de \\ Atenção Psicossocial

\begin{abstract}
Motivaciones y repercusiones del consumo de crack: el discurso colectivo de usuarios de un Centro de Atención Psicosocial
\end{abstract}

Milca Ramaiane da Silva Carvalho ${ }^{1}$ Janaina Raquel de Souza Silva ${ }^{2}$ Nadirlene Pereira Gomes ${ }^{3}$

Magna Santos Andrade ${ }^{1}$

Jeane Freitas de Oliveira ${ }^{3}$

Márcia Rebeca Rocha de Souza ${ }^{4}$

\section{State University of Bahia.}

Senhor do Bonfim. Bahia. Brazil.

2. Territorial Center of Professional Education

of Sisal. Serrinha. Bahia. Brazil.

3. Federal University of Bahia.

Salvador. Bahia. Brazil.

4. Hall City of Macaé.

Macaé. Rio de Janeiro. Brazil.
Corresponding Author:

Milca Ramaiane da Silva Carvalho.

E-mail: milca_enf@hotmail.com.

Submitted on $07 / 06 / 2016$.

Accepted on 10/31/2016.

DOI: 10.1590/2177-9465-EAN-2016-0178

\begin{abstract}
Aim: To identify the motivations and repercussions related to crack consumption by people attending a Centro de Atenção Psicossocial Álcool e Drogas (CAPS AD) (Psychosocial Care Center Alcohol and Drugs) in Bahia. Method: This is a qualitative study developed with eight crack users attending a CAPS AD in a city of Bahia. Interviews, whose content was organized by the technique of the Collective Subject Discourse, were conducted in October and November 2013. Results: The study reveals that the curiosity and the desire to belong to peer groups are events that motivate crack experimentation, and its consumption triggers aggressive and paranoid behavior, depression, financial losses and family and friends abandonment. Conclusion: Given the consequences to social relations and health, actions to prevent the use and consumption of crack are necessary, particularly in order to intervene on the motivations that prompt the first use and relapse.
\end{abstract}

Keywords: Drug User; Crack Cocaine; Nursing.

\section{REsUmo}

Objetivo: Identificar as motivações e repercussões relacionadas ao consumo do crack por pessoas atendidas em um Centro de Atenção Psicossocial Álcool e Drogas (CAPS AD) no interior da Bahia. Método: Estudo de abordagem qualitativa desenvolvida com oito usuários de crack atendidos em um CAPS AD de um município baiano. Realizaram-se entrevistas nos meses de outubro e novembro de 2013, cujo conteúdo foi organizado pela técnica do Discurso do Sujeito Coletivo. Resultados: O estudo revela que a curiosidade e o desejo de pertencer aos grupos de pares são eventos que motivam a experimentação do crack, cujo consumo desencadeia comportamento agressivo e paranoico, depressão, prejuízos financeiros e abandono familiar e de amigos. Conclusão: Diante as repercussões sociais e para a saúde, tornam-se necessárias ações para a prevenção do uso/consumo do crack, sobretudo no sentido de intervir sobre as motivações que incitam o primeiro uso e as recaídas.

Palavras-chave: Usuário de drogas; Cocaína Crack; Enfermagem.

\section{Resumen}

Objetivo: Identificar las motivaciones y repercusiones relacionadas al consumo de crack por personas atendidas en un CAPS AD en el interior de Bahía. Método: Estudio de abordaje cualitativo desarrollado con ocho usuarios de crack atendidos en un Centro de Atención Psicosocial de alcohol y drogas de un municipio bahiano. Se realizaron entrevistas en octubre y noviembre de 2013, cuyo contenido fue organizado por la técnica del Discurso del Sujeto Colectivo. Resultados: El estudio revela que la curiosidad y el deseo de pertenecer a los grupos de pares son eventos que motivan la experimentación del crack, cuyo consumo desencadena comportamiento agresivo y paranoico, depresión, perjuicios financieros y abandono familiar y de amigos. Conclusión: Frente a las repercusiones sociales y para la salud, son necesarias acciones para la prevención del uso/consumo de crack, sobretodo en el sentido de intervenir sobre las motivaciones que incitan al primer uso y las recaídas.

Palabras clave: Usuario de drogas; Cocaína Crack; Enfermería. 


\section{INTRODUCTION}

Crack consumption remains high, despite the fact that the World Drug Report demonstrates an overall downward trend for the consumption of cocaine, which is the base substance of this drug. On the international scene, it is predominant in Western and Central Europe, North America and Australia. ${ }^{1}$ In Brazil, crack has reached almost all the territorial extent of Brazilian cities, including some isolated indigenous villages. The process in which the drug reaches all regions of the country, including the countryside, especially in low-income districts, is directly linked to the ease of use and reduced price. ${ }^{2}$

Brazil is considered the largest crack market in the context of South America, with more than 900,000 users in the year 2010, ${ }^{3}$ which is equivalent to about $1 \%$ of the Brazilian population. ${ }^{1}$ Regarding the number of users, there is a consumption increase forecast in the country over the years. This trend could be demonstrated when comparing 2005 data, when it estimated a quantity of 370,000 dependent users of the drug. ${ }^{4}$

The increase in the number of crack users over the years has led health services to continuously receive this demand. ${ }^{3}$ In 2003, the consumption of this substance accounted for approximately $70 \%$ of admissions. ${ }^{5}$ Within the Sistema Único de Saúde (SUS) (Unified Health System), the service reference is the Centro de Atenção Psicossocial Álcool e Drogas (CAPS AD) (Psychosocial care Center Alcohol and Drugs). ${ }^{6}$ In this specialized care space, the goal is to seek the identification and reception of persons with problems arising from drug abuse in order to provide better assistance to these individuals. For this, there must be effective actions of government and society that consider the dissemination of studies on the use of crack, as well as health promotion and expansion of the service network for the treatment of the population that makes use of this drug.

Taking into account that knowledge on this phenomenon is an essential tool for the professional training process for actions in care for crack users and prevention of this disease, the question is: What are the motivations to start using crack? What are the effects of the consumption of this substance? Given these concerns, the following objective was outlined: identify the motivations and repercussions related to crack consumption by people assisted in a CAPS AD in Bahia.

\section{METHOD}

This is an exploratory and descriptive study using a qualitative approach, linked to the project entitled "crack users' discourse on drug use and the relationship with the family" carried out in a CAPS AD located in a municipality in the state of Bahia, Brazil.

The mentioned service is specialized on the full and continuous attention to people with needs related to alcohol, crack and other drugs. Currently, it assists 403 people registered and its team consists of eight health professionals (psychiatrist, nurse, psychologist, occupational therapist, social worker, pharmacist and nursing technicians), as well as the administrative staff.
The identification of potential collaborators occurred exclusively from hospital records, in order to identify those with crack consumption history who met the following criteria: be aged 18 years or over, crack user, be registered in the unit, attend activities according to an individual treatment plan, and be psychologically able to participate in the survey as evaluation of service psychologist. In this context, eight people who met the previously established criteria were identified between October and November 2013.

Respecting the ethical aspects, the participants were informed about the purpose and relevance of the study, the right to decide to participate in the research and desist at any stage, with no impairment of care in the unit. They were also informed about the confidentiality of the statements, which were identified by the letter E, followed by an Arabic number. All participants signed a consent form. The project was approved by the Ethics Committee of the State University of Bahia (Opinion No. $424,473 / 2012)$.

The data collection technique used was the interview, which is the interaction between researcher and participant. This interview was guided by a semi-structured form, which included closed questions on socio-economic aspects, in order to characterize the employees, and two guiding: Tell me how you started using crack and; tell me about the effects of crack use. The interview took place in the unit, in a private environment, seeking the privacy of employees. The content of the interviews was recorded in digital equipment and was fully transcribed.

As this is a discursive methodological strategy of organization and characterization of information obtained by interview, the Collective Subject Discourse (CSD) was used. This technique fits the studies that seek social representations or collective opinions and it is a strategy that transforms individual statements into collective representations.

Following the CSD assumptions, after transcribing the interviews, we sought to identify the individual lines, the sections that correspond to the same testimony content characterized as Keywords (KWS). Of these, the Core Ideas (CI) were extracted. After identifying the interviews that contemplated the same methodological figures, there was the creation of the CSD, which constitutes a written speech synthesis in the first person singular, which included the KWS who had the same $\mathrm{Cl}$. Data analysis was based on issues related to crack.

\section{RESULTS}

Regarding the sociodemographic characteristics, of the eight people interviewed, five were men. Age ranged from 29 to 53 years. The people were predominantly black and single, had children, incomplete primary education, monthly income below the minimum wage, and stated that they depended financially on a family member. Regarding the use of drugs, employees reported consuming crack for an average of six years, and its association with other psychoactive substances, including alcohol, marijuana and cocaine, is common. 
In the analysis process two categories were identified: Motivations and Repercussions. These were subdivided into central ideas Synthesis, as Table 1.

Table 1. Categories and central ideas formed by the narratives of the participants.

\begin{tabular}{|ll|}
\hline CATEGORY & CENTRAL IDEA \\
\hline Motivations & IC 1: Curiosity \\
& IC 2: Desire to belong to peer groups \\
Repercussions & IC 3: Change in behavior \\
& IC 4: Feelings of loss and humiliation \\
\hline
\end{tabular}

\section{Central idea Synthesis 1 - Curiosity}

It is evident that the beginning of crack consumption for employees was related to curiosity.

The drug began as a curiosity. [...] I've always been curious, especially in adolescence. [...] Because of curiosity, I tried it. [...] But it was a bewilderment of mine to use it by curiosity! [...] I used it and became dependent. $(E 1, E 2, E 3, E 5, E 8)$

\section{Central idea Synthesis 2 - Desire of belonging to peer groups}

For the respondents, the beginning of crack use was associated with the desire to belong to peer groups, particularly through the influence of friends.

I started using crack through a friend. [...] I tried it by the influence of friends. In the artistic circles, everyone smokes a joint, smells powder, have a beer! I myself only used for fun. $(E 1, E 2, E 5, E 6, E 8)$

Besides being the trigger element to the beginning of crack use, reports indicate the influence of the social context for relapse, again highlighting the influence of friends. We can also point out that the detachment from the influence of the group is characterized as a protective factor for non-consumption of crack:

In the place where I worked the boss and the staff knew I smoked, but I did not want to use it there. I never felt like it! I don't know why I want to use the crack in my town! I was almost a year without using it! After I got here it was a temptation! [...] I had a relapse but I don't know why it happened. I spend a month without using the drug. [...] Sometimes I spend up to two months without it. I already spent six months without using it. [...] But when I got here, I started using it again. I don't know why I want to use it when I come here, [...] but it keeps repeating it into my head: "use it, use it, use it", then I use it! (E1, E2, E4, E5, E7).

\section{Central idea Synthesis 3 - Change in behavior}

Employees reported that the use of crack resulted in aggressive reactions, depression and paranoia in everyday situations, as shown in the following speech:

Before the drug, I didn't use to fight with anyone. My life was good: I didn't fight with my children. With the crack, if somebody looks at me in the face, I get ready to fight! When I use it, I become aggressive. I get nasty when I use crack! I have already fought at a bar and I even used a knife and everything. [...] It's something that comes out of the blue [...] and I get really crazy! I get blind! [...] Then I feel a certain depression and paranoia! (E1, E2, E5, E7)

\section{Central idea Synthesis 4 - Feelings of loss and humiliation}

The speech revealed feelings of loss and humiliation associated with consumption of crack. The losses were related to isolation from family, friends, money, causing them to experience humiliating situations.

It is a miserable drug! After I got into this life, I was done! I got sad! Humiliated! You can't keep money in your pocket. [...] I got away from my family, from my friends. I no longer had anything! Those who used the drug with me told me they were my friends, but it was quite the opposite! I know it was a misery, the extermination of my life and the lives of my family. It was total misery! Until today I have striking trauma, not only in my flesh, but also in my spirit. [...] I went through many things; I even got close to death! It was something that did not bring me any good. It brings only destruction. Crack was rock bottom for me! (E1, E3, $E 5, E 6, E 7, E 8)$

\section{DISCUSSION}

The study reveals that one of the motivations that instigate the first crack consumption is curiosity. This is an essential feature of human existence, which is the continuing desire for experiencing something new. The curiosity is sharpened by the world unveiling, expanding and even encouraging experimentation of potential risky behaviors, especially in adolescence. Corroborating, research conducted with adolescents in Portugal, ${ }^{7}$ Nicaragua $^{8}$ and $\mathrm{Brazi}^{9}$ show curiosity as the influence factor for the onset of crack use.

As well as curiosity, another feature that generates vulnerability to drug use is the desire to belong to peer groups. Being inserted in these groups is necessary for psychosocial development, and represents an established space for "equals" to externalize feelings, alleviate impotence and share questions and confrontations. Research conducted in Peru and Brazil also argue that people, especially teenagers, take refuge in peer groups to solidify a social group identity, in which they feel 
comfortably welcomed. ${ }^{10,11}$ This group is the social reference capable of encouraging the sharing of new models of conduct.

Therefore, it is common for individuals to imitate peers, reproducing attitudes and costumes of their group. Perceived as a reassuring model, imitating peers also happens to be understood as a prerequisite for achieving popularity, power and social acceptance.$^{12}$ In this context, the pressure that the group can exerts is seen as a legitimization that validates whether the person has the possibility of belonging or not to the group. However, one must weigh the risk of these alliances to the lives of individuals, as they acquire a connotation of testing for the hosting within the groups' habitat. Regarding drug use, given the pressure that the group of friends exercises, saying "no" becomes just a hypothesis combined in the social imaginary of people. ${ }^{13}$

The aggravating in this situation is that the initial idea of a casual experience, prompted by curiosity and/or friends, can turn into an ongoing relationship, as the physical and psychological dependence caused by the psychoactive substance. ${ }^{14}$ This situation in which the individual perceives to be dependent, as assumed by the collective subject of the study, can be explained because the attitudes and behaviors adopted were based on decisions in the present, without necessarily a reflection in terms of its repercussions, which can be configured as a risk behavior. However, it must be considered that, especially for adolescents, taking such conduct is a strategy to exercise power over the new and the unknown, and to meet the need of individualization and development of autonomy, with no spaces to rethink their developments. ${ }^{15}$

Although there is no awareness in terms of implications when individuals start using crack cocaine at some point the collective subject recognizes the destructive nature of the drug, when he reports "[...] it was a bewilderment of mine [...] I used it and became dependent". The aggressiveness frame, depression, paranoia, as well as financial loss and family and friends, unveiled in this study, were also pointed out in other studies in Brazil. ${ }^{16-18}$ The repercussions collaborate to the development and worsening of impulsivity, which directs individuals to do more shortsighted choices without assessing the impact. ${ }^{19}$

Regarding mental health, a study conducted in the United State ${ }^{20}$ confirms that the use of crack is significantly associated with high levels of depression. Research conducted in Nicaragua also adds risk of anxiety, bipolar disorder and schizophrenia. ${ }^{21}$

The reduction in financial condition was also identified in a study ${ }^{18}$ conducted with drug users treated at a rehabilitation clinic for drug addicts in the state of Paraná, Brazil. The results showed that $77 \%$ of respondents reported having lost their jobs because of crack use, revealing the financial imbalance as one of the consequences of such conduct. Job loss and financial problems, as well as instability or disruption of family and romantic relationships, are events that predispose the search for strategies to support and treatment. However, although they long for ceasing drug use, crack users recognize that this is a difficult task, ${ }^{9}$ especially if inserted in the social sphere of influence, which favors relapses..$^{22} \mathrm{~A}$ study conducted in Antigua and Barbuda, an independent country in the Americas, in which abstinence in 100 patients in the treatment program against drugs and alcohol was evaluated, it was found that the risk of relapse was higher in patients who were using crack cocaine: $67 \%$ of relapses occurred in people who used crack cocaine as the primary drug ${ }^{23}$ demonstrating the challenge that permeates the abandonment of addiction.

Specifically on the affective abandonment, the isolation from family and friends, it was also recognized in a study involving 111 adolescents in a public school in Rio de Janeiro, Brazil. ${ }^{24}$ Sometimes crack users identify the family as a single "personal" network of support. ${ }^{22}$ Although it is a common reality for drug users in general, this support is essential for the care of these individuals. Family support, therefore, assumes a prominent role, since it broadens the chances of reduction of drug use, and it also promotes relapse prevention. ${ }^{17}$

Therefore, the partnership between the health sector and family is extremely important, since the family most often does not know how to handle the situation and, for this reason, requires institutional support in order to facilitate the negotiation of care aimed to the subject. Thus, intervention strategies that include health professionals and family members, such as participatory therapeutic projects guided by the context of life and need of users, should be potentialized. ${ }^{25}$

In the context of primary health care, nurses play a fundamental role in health education promotion in order to achieve a healthier standard of living and hence reduce the risk of consumption of crack and other drugs through the motivation to self-care. ${ }^{9}$ By comprising the influence of friends and curiosity in terms of crack consumption, responsible for damages to family, finances and health, one must be attentive to an increased vulnerability, especially in adolescence, both for the first experiment and for relapses. This aspect needs to be contemplated in the planning of actions in order to consider the risk related to the reproduction of the actions of peer groups the individual identification of positive references; and the construction of the character.

It is important to note that the realization preventive actions in social spaces, such as family and school, will allow the identification of vulnerable individuals and/or who already consume crack; the latter should be subject to later interventions. A study carried out in the state of Espírito Santo, ${ }^{25}$ proposing a care strategy for crack users, said that nurses can represent an important identification and reframing agent of socialization institutions, with emphasis to school, religion, family, the media among other institutions that play the social role of diffusing values.

During care provided to individuals who consume crack, nurses must value the use of motivational strategies, encouraging the reinterpretation and identification of solutions to the problems that lead to consumption and the negotiation of tasks that can be achieved. ${ }^{25}$ Thus, unique strategies are sought so that 
individuals can recognize themselves as social subjects capable of living healthily within their contexts and choices. ${ }^{26}$

\section{CONCLUSION}

The speeches of the subjects reveal that curiosity and the desire to belong to peer groups are events that motivate crack trial, and the consumption of such drug triggers aggressive and paranoid behavior, depression, financial losses and the abandonment of family and friends.

Given the implications for social relations and health, action to prevent the use/consumption of crack must be taken, especially in order to intervene on the motivations that incite the first use and relapse. We can highlight the role of relevance of nurses, since they integrate the reference teams in the Family Health Strategy and CAPS and often take charge of the coordination of health facilities and technical areas in the health secretaries at the municipal, state and federal levels. From this perspective, health professionals are in a prominent position in the development of coordinated actions with educational institutions and the family.

\section{REFERENCES}

1. United Nations Office on Drugs and Crime (UNODC). Global Illicit Drug Trends. [Internet]. Vienna: UNODC; 2015 [cited 2016 May 15]. Available from: https://www.unodc.org/documents/wdr2015/World Drug_Report_2015.pdf

2. Confederação Nacional de Municípios (BR). Observatório do Crack: os municípios brasileiros como protagonistas no enfrentamento ao crack [Internet]. Porto Alegre (RS): Confederação Nacional de Municípios: 2012 [cited 2014 Jun 10]. Available from: http://portal.cnm.org.br/ sites/5700/5770/07112011_EstudoTecnicoColetivadoCrack_versao_ Final.pdf

3. United Nations Office for Drug Control and Crime (UNODCCP). Word Drug Report 2010. [Internet]. Vienna: UNODCCP;2010 [cited 2016 Aug 03]. Available from: https://www.unodc.org/documents/wdr/WDR_2010/ World_Drug_Report_2010_lo-res.pdf

4. Ministério da Justiça (BR). Secretaria Nacional de Políticas sobre drogas. Pesquisa Nacional sobre o uso de crack e outras drogas - Quem e Quantos são [internet]. Brasília (DF): Secretaria Nacional de Políticas sobre drogas; 2013 [cited 2016 May 18]. Available from: http://www. observasmjc.uff.br/psm/uploads/Pesquisa_Nacional_sobre_uso_de_ crack_e_outras_drogas.pdf

5. Ferreira Filho OF, Turchi MD, Laranjeira R, Castelo A. Perfil sociodemográfico e de padrões de uso entre dependentes de cocaína hospitalizados. Rev Saúde Pública [Internet]. 2003 [cited 2016 Mar 22]; 37(6)751-9. Available from: $h$ ttp://www.scielo.br/pdf/rsp/v37n6/18018.pdf

6. Horta RL, Horta BL, Rosset AP, Horta CL. Perfil dos usuários de crack que buscam atendimento em Centros de Atenção Psicossocial. Cad. Saúde Pública [Internet]. 2011 [cited 2016 Sep 10]; (11):2263-70. Available from: http://www.scielo.br/pdf/csp/v27n11/19.pdf. http://dx.doi. org/10.1590/S0102-311X2011001100019

7. Neto C, Fraga S, Ramos E. Illicit substance use by Portuguese adolescents. Rev Saúde Pública [Internet]. 2012 [cited 2016 May 20]; 46(5):808-15. Available from: http://www.scielo.br/pdf/rsp/v46n5/en_07. pdf. http://dx.doi.org/10.1590/S0034-89102012000500007

8. Morales-Alfaro JR, Herrera A, Zanetti ACG, Gherardi-Donato ECS. Approaching the world of young drug users: a qualitative study in Nicaragua. SMAD, Rev Eletrônica Saúde Mental Álcool Drog [Internet]. 2014 [cited 2016 Sep 15]; 10(3):143-50. Available from: http://www. revistas. usp.br/smad/article/view/98732/97294. doi: 10.11606/ issn.1806-6976.v10i3p143-150
9. Gabatz RIB, Schmidt AL, Terra MG, Padoin SMM, Silva AA, Lacchini AJB. Perception of crack users in relation to use and treatment. Rev Gaúcha Enferm [Internet]. 2013 [cited 2016 Mar 22]; 34(1):140-6. Available from: http://www.scielo.br/pdf/rgenf/v34n1/en_18.pdf. http:// dx.doi.org/10.1590/S1983-14472013000100018

10. Cavalcante MBPT, Alves MDS, Barroso MGT. Adolescência, álcool e drogas: uma revisão na perspectiva da promoção da saúde. Esc Anna Nery [Internet]. 2008 jul-set [cited 2016 Sep 10]; 12(3):555-9. Available from: http://www.scielo.br/pdf/ean/v12n3/v12n3a24.pdf. http://dx.doi. org/10.1590/S1414-81452008000300024

11. Gil HLB, Mello DF, Ferriani MGC, Silva MAI. Perceptions of adolescents students on the consumption of drugs: a case study in Lima, Peru. Rev Latino-Am Enfermagem [Internet]. 2008 [cited $2016 \mathrm{Apr}$ 18]; 16(Esp.):551-7. Available from: http://www.scielo.br/pdf/rlae/ v16nspe/08.pdf. http://dx.doi.org/10.1590/S0104-11692008000700008

12. Barbosa MR, Matos $P M$, Costa ME. As relações de vinculação e a imagem corporal: exploração de um modelo. Psic Teor Pesq [Internet] 2011 jul-set [cited 2016 May 20]; 27(3):273-82. Available from: http:// dx.doi.org/10.1590/S0102-37722011000300002

13. Bernardy CCFI, Oliveira MLF, Bellini LM. Jovens infratores e a convivência com drogas no ambiente familiar. Rev Rene [Internet] 2011[cited 2016 Mar 22]; 12(3):589-96. Available from: http://www. periodicos.ufc.br/index.php/rene/article/view/4294/3306

14. Moura HF, Benzano D, Pechansky F, Kesslem FHP. Crack/cocaine users show more family problems than other substance users. Clinics [Internet]. 2014 Jul [cited 2016 Apr 18]; 69(7):497-9. Available from: http://www.scielo.br/pdf/clin/v69n7/1807-5932-clin-69-07-497.pdf http://dx.doi.org/10.6061/clinics/2014(07)10

15. Santos MA, Pratta EMM. Adolescência e uso de drogas à luz da psicanálise: sofrimento e êxtase na passagem. Tempo Psicana [Internet]. 2012 [cited 2016 May 20]; 44(1):167-82. Available from: http:// pepsic.bvsalud.org/pdf/tpsi/v44n1/v44n1a10.pdf

16. Fertig A, Souza LM, Schneider JF. The daily life of relatives of crack users: a reflective analysis. J Nursing UFPE on line [Internet]. 2013 [cited 2016 Apr 18]; 7(Esp.):5726-32. Available from: http://www.revista.ufpe. br/revistaenfermagem/index.php/revista/article/view/4837/pdf_3496

17. Rezende MM, Pelicia B. Representation of crack addicts relapse. SMAD, Rev Eletrônica Saúde Mental Álcool Drog [Internet]. 2013 May-Aug [cited 2016 Mar 22]; 9(2):76-81. Available from: http://pepsic.bvsalud.org/pdf/ $\mathrm{smad} / \mathrm{v} 9 \mathrm{n} 2 / 05 . \mathrm{pdf}$

18. Silva LHP, Borba LO, Paes MR, Guimarães AN, Mantovani MF, Maftum MA. Perfil dos dependentes químicos atendidos em uma unidade de reabilitação de um hospital psiquiátrico. Esc Anna Nery [Internet ]. 2010 Jul-Set [cited $2016 \mathrm{Jul}$ 02]; 14(3):585-90. Available from: http://eean. edu.br/detalhe_artigo.asp?id=575. http://dx.doi.org/10.1590/S1414 81452010000300021

19. Kessler F, Pechansky F. Uma visão psiquiátrica sobre o fenômeno do crack na atualidade. Rev Psiquiatr RS [Internet]. 2008 [cited 2016 Mar 22]; 30(2):96-8. Available from: http://www.scielo.br/pdf/rprs/v30n2/ v30n2a03

20. Latkin C, Davey-Rothwell M, Yang J, Crawford N. The Relationship between Drug User Stigma and Depression among Inner-City Drug Users in Baltimore, MD. J Urban Health [Internet]. 2013 [cited 2016 Apr 18]; 90(1):147-56. Available from: https://www.ncbi.nlm.nih.gov/pmc/ articles/PMC3579309/pdf/11524_2012_Article_9753.pdf. doi:10.1007/ s11524-012-9753-z

21. Kulakova OV, Mann R, Strike C, Brands B, Khenti A. Comorbilidad entre distrés psicológico y abuso de drogas en pacientes de centros de tratamiento: implicaciones en políticas y programas, Managua Nicaragua. Texto Contexto Enferm [Internet]. 2012 [cited 2016 Apr 22] 21(Esp):141-9. Available from: http://www.scielo.br/pdf/tce/v21nspe/ v21nspea18.pdf. http://dx.doi.org/10.1590/S0104-07072012000500018

22. Paula ML, Jorge MSB, Albuquerque RA, Queiroz LM. Crack users in treatment: experiences, meanings and senses. Saude Soc [Internet] 2014 [cited 2016 Apr 18]; 23(1):87-98. Available from: http://www.scielo. $\mathrm{br} / \mathrm{pdf} / \mathrm{sausoc} / \mathrm{v} 23 \mathrm{n} 1 / \mathrm{en}$ 0104-1290-sausoc-23-01-00118.pdf. http:// dx.doi.org/10.1590/S0104-12902014000100009 
23. Martin TC, Josiah-Martin JA, Kosakoski J, Norton K, Sinnott T. A comparison of patients relapsing to addictive drug use with nonrelapsing patients following residential addiction treatment in Antigua. West Indian Med J [Internet]. 2005 [cited 2016 Apr 18]; 54(3):196-201. Available from: http://dx.doi.org/10.1590/S0043-31442005000300008

24. Lopes GT, Bernardes MMR, Ribeiro APLP, Belchior PC, Delphim LM, Ferreira RS. Perceptions of adolescents regarding drug use/addiction theater as the pedagogical strategy. Esc. Anna Nery [Internet]. 2014 Apr-Jun [cited 2016 Feb 06]; 18(2):202-8. Available from: http://www. scielo.br/pdf/ean/v18n2/en_1414-8145-ean-18-02-0202.pdf. http:// dx.doi.org/10.5935/1414-8145.20140029
25. Wandekoken KD, Siqueira MM. Aplicação do Processo de Enfermagem a usuário de crack fundamentado no modelo de Betty Neuman. Rev Bras Enferm [Internet]. 2014 [cited 2016 Feb 05]; 67(1):62-70. Available from: http://www.scielo.br/pdf/reben/v67n1/0034-7167reben-67-01-0062.pdf. http://dx.doi.org/10.5935/0034-7167.20140008

26. Pavanatto PA, Gehlen MH, Ilha S, Zamberlan C, Rangel RF, Nietsche EA. Contributions of ludic care in nursing to chemical detoxification due to the use of crack cocaine. Rev Gaúch Enferm [Internet]. 2015 [cited 2016 Jan 17]; 36(2):50-5. Available from: http://www.scielo. br/pdf/rgenf/v36n2/1983-1447-rgenf-36-02-00050.pdf. http://dx.doi. org/10.1590/1983-1447.2015.02.48736 